\title{
Does Corruption in a Country Affect the Foreign Direct Investment? A Study of Rising Economic Super Powers China and India
}

\author{
Siva Prasad Ravi \\ School of Business and Economics, Thompson Rivers University, Kamloops, Canada \\ Email: Rprasad@tru.ca
}

Received 19 May 2015; accepted 11 July 2015; published 14 July 2015

\begin{abstract}
Many researchers have studied the effect of corruption on Foreign Direct Investment (FDI) and majority of them have come to the conclusion that higher levels corruption in a country deter FDI. This paper is a case-based comparative study of the effect of corruption on FDI in China and India. Corruption in India has negatively affected FDI, whereas that is not true in China. This study finds that while corruption does affect FDI inflows into a country, the effect also depends on nature of corruption and not only on size of corruption.
\end{abstract}

Keywords

Corruption, Direct Investment (FDI), Comparative Study, China, India

\section{Introduction}

Foreign Direct Investment (FDI) has become very important for developing countries as well as developed countries. FDI has become a de-facto proxy for assessing the attractiveness of a country for international business. FDI is an investment by an investor from one country in a foreign country by acquiring at least $10 \%$ of a company's capital or by creating a new business entity in the host country (UNCTAD, 2014) [1]. The Chinese and Indian Economies have been growing at an unprecedented pace during the last two decades, but unfortunately the same is also true with corruption. Corruption also distorts allocation of resources, indirectly contributing to increase in prices and discourages FDI. High levels of corruption in India have adversely affected inward FDI into India, but that is not the case with China. The layout of the rest of the paper is as follows. Part 2 explains the methodology, Part 3 compares India and China, Part 4 examines the global foreign direct investment, Part 5 analyses FDI in China and India, Part 6 deals with corruption in China and India, Part 7 discusses effect of corruption on FDI in China and India, Part 8 is the discussion and findings, and Part 9 concludes the study.

\section{Methodology}

This study will use a mix of qualitative and quantitative methods and secondary sources for data, mainly cases.

How to cite this paper: Ravi, S.P. (2015) Does Corruption in a Country Affect the Foreign Direct Investment? A Study of Rising Economic Super Powers China and India. Open Journal of Social Sciences, 3, 99-104.

http://dx.doi.org/10.4236/jss.2015.37017 
For the discussion on issues like corruption and foreign direct investment, where a number of mainly qualitative factors need to be included in the study, case study approach has been found to be very effective (Lee, 1989). There are few comparative studies on effect of corruption on FDI inflows into China and India. This study hopes to fill that gap.

\section{China and India}

China and India have a number of similarities and many differences. China and India are the two ancient civilizations in the world. China has a population of 1.4 billion and India 1.2 billion India is world's largest democracy whereas China is a communist country. China has initiated the economic reforms during mid 1980s and India in early 1990s. Since then, China and India have come a long way. During 2014 China has achieved the distinction of largest economy, with highest GDP in the world, US\$17617.3 billion and attracted highest FDI. India has become the third largest economy in the world, US\$ 7375.9 billion (International Monitory Fund, 2014) $[2]$.

\section{Foreign Direct Investment}

The International Monetary Fund (IMF) defines FDI as investment in " incorporated or unincorporated enterprise in which a foreign investor owns 10 percent or more of the ordinary shares or voting power of an incorporated enterprise or the equivalent of an unincorporated enterprise" (IMF 2004) [3]. According to the World Investment Report published by UNCTAD (2014) [1] international FDI inflows increased by 9 percent in 2013 to US\$ 1.45 trillion. Developing countries attracted 54\% of all the inward FDI and Asia attracted more inward FDI than Europe or United States. Developing and underdeveloped economies do not have the required income levels or internal savings that can meet the demand for investment required to create sustainable economic growth. FDI fills the gap between the demand and supply of the economic and other resources (Anita, 2012; Alemu, 2012) [4] [5].

\section{Analysis of FDI into India and China}

Indian economy currently is the third largest economy in the world by Purchasing Power Parity. After an average annual growth rate of 7.05 percent during last 10 years, but slowed down during 2012 to 4.7 percent and 5.0 percent in 2013 (World Bank, 2014) [6]. FDI into India till 1990 was very low, due to the "socialist" economic policies followed by the government. FDI was discouraged during 1960s and 1970s, and FDI inflows started improving after the economic reforms were initiated in 1990s. During 2014 India attracted FDI of US\$ 42.00 billion

China in initial years after revolution has discouraged foreign investment. With the initiation of economic reforms during 1980s, China has opened its doors for FDI in a limited and selective way. During 1980s and 1990s China permitted FDI in selected industries and selected special economic zones and export oriented manufacturing. Provinces have been establishing "one stop" facility for allowing investors By 2010, according to China's Ministry of Commerce, enterprises with FDI accounted for $50 \%$ of the total imports and exports, 30\% of industrial output and $22 \%$ of industrial profits and FDI has "catalyzed" China's economic reform (The world Bank, 2010) [7]. China has become the most sought after destination for all types business across the world for manufacturing their products. Table 1 shows the FDI inflows into India during last 10 years.

\section{Corruption in India and China}

Corruption in the world has existed for centuries. Corruption exists both in both developing and developed countries. Corruption is a complex and distinct phenomenon. Transparency International (TI), the corruption watchdog of the world defines corruption as "misuse of entrusted power for private gain". Corruption according

Table 1. FDI inflows into india and China 2004-2014 in US\$ Billions.

\begin{tabular}{ccccccccccccc}
\hline Year & 2004 & 2005 & 2006 & 2007 & 2008 & 2009 & 2010 & 2011 & 2012 & 2013 & 2014 \\
\hline FDI India & 5.78 & 7.62 & 20.33 & 25.35 & 42.55 & 35.65 & 24.64 & 36.19 & 24.20 & 28.20 & 42.00 \\
FDI China & 60.6 & 72.4 & 77.7 & 83.5 & 108.3 & 95 & 114.7 & 123.9 & 121.0 & 123.9 & 128.0 \\
\hline
\end{tabular}

Source: World Development Indicators, 2014. 
to UNDP is principally a governance issue, reflection of institutional failure or lack of capacity on the part of government to manage society by means of a framework of social, judicial, political and economic checks and balances. UNDP defines corruption as the misuse of public power, office or authority for private benefitthrough bribery, extortion, influence peddling, nepotism, fraud, speed money or embezzlement Robert Klitgaard's (1995) [8] equation summarizes the corruption framework effectively as "Corruption = Monopoly + Discretion - Transparency (in governance)". Corruption in a country can be classified into three levels. The first one is petty bureaucratic corruption that takes place at the lowest level like in government offices. The second level is administrative corruption, involving senior administrative officials of the government and the third or highest level is at the political level, what is known as 'grand larceny' (Pathak and Prasad, 2006) [9].

According to Transparency International both India and China have high levels of corruption. Table 2 is a compilation of Transparency International's Corruption Perception Index (CPI) for India from 1995 to 2014. The CPI score is on a scale of 1 to 10 , where a high score is an indication of low levels of corruption and low score is an indication of high levels of corruption in a country. With regards to the rank, the higher the rank, the higher the corruption. A cursory look at these figures indicates that corruption is a major problem in India and China.

Lee and Oh, (2007) [10] studied corruption in Asia from the point of view of pervasiveness and arbitrariness and came to the conclusions that foreign investors may not get deterred by pervasiveness of corruption but may not invest if arbitrariness is high in a country.

During the last two decades the nature of corruption in India has changed. From 1950 to 1980s the petty corruption and administrative corruption were more prominent, but starting from $1980 \mathrm{~s}$, the political corruption has become the more predominant. During the last decade, starting from 2000 till 2012 India has witnessed unprecedented political corruption both in quantity and number of cases. Some of the corruption scandals include Bofors (1986, US\$ 285 million), HDW submarine Scandal (1987, US\$ 68.85 million), Securities Scam (1992, $\$ 1.65$ billion), Ketan Mehta Stock Market Scam (2001, US\$ 200 million), Satyam Computers scam (2009, US\$ 1.47 billion), Commonwealth Games scam (2010, US\$ 1.31 billion), 2G spectrum scam (2010, US\$ 40 billion), Coalmine allocation scam (2012, US\$ 40 billion) (Business Today, 2014; Financial Times, 2014) [11] [12].

According to Huang, China has a history of corruption, but the present-day corruption has its source in economic reforms as an unintended by product. Culturally, Chine society works around a concept called 'Guan Xi' or relationships. It is known fact that in China to be able to transact business one needs a strong network of friends, who help each other and that is at the heart of "Guan Xi". Another cultural aspect of Chinese society is that of gift giving. In the initial stages of reforms, unscrupulous businesses made huge profits by manipulating the local officials and deriving "price arbitrage". The officials benefited from the gifts and bribes. Due to the language barriers and lack of knowledge about local practices international investors had to take local firms as agents or partners and in many cases these agents or partners did the ground work. This arrangement suited many investors as this speeded up the process of getting the required permits from the local officials and also fuelled corruption. Most researchers are of the opinion that corruption retards economic growth, but in case of China this did not prove to be true. In case of China "the opposite seems to be happening" (Huang, 2015) [13].

The ever growing corruption has become a cause of worry for the Chinese's government. This has culminated in President Xi Jinping's anti-corruption drive after assuming the office in 2012, in which he promised to go after both 'Tigers and Flys', to root out corruption. As a result of his campaign, till date, 414,000 officials have been disciplined and 201,600 officials were investigated and punished till 2013. Some senior officials caught were, the deputy Chief Engineer of the Railawy Ministry, who was in charge of the projects liking China with

Table 2. CPI score and TI rank/Total number of countries India and China 1995-2014.

\begin{tabular}{|c|c|c|c|c|c|c|c|c|c|c|c|c|c|c|c|c|c|c|c|c|}
\hline Year & 1995 & 96 & 97 & 98 & 99 & 2000 & 01 & 02 & 03 & 04 & 05 & 06 & 07 & 08 & 09 & 2010 & 11 & 12 & 13 & 14 \\
\hline $\begin{array}{c}\text { CPI } \\
\text { India }\end{array}$ & 2.78 & 2.76 & 2.75 & 2.9 & 2.9 & 2.8 & 2.7 & 2.7 & 2.8 & 2.8 & 2.9 & 3.3 & 3.5 & 3.5 & 3.4 & 3.3 & 3.1 & 36 & 36 & 38 \\
\hline $\begin{array}{c}\text { CPI } \\
\text { China }\end{array}$ & 2.16 & 2.43 & 2.88 & 3.5 & 3.4 & 3.1 & 3.5 & 3.5 & 3.4 & 3.4 & 3.8 & 3.3 & 3.5 & 3.6 & 3.6 & 3.5 & 3.6 & 39 & 40 & 36 \\
\hline $\begin{array}{l}\text { Rank } \\
\text { India }\end{array}$ & & $46 / 54$ & $45 / 52$ & $66 / 85$ & $72 / 99$ & $69 / 90$ & $71 / 91$ & $71 / 102$ & $83 / 133$ & $90 / 145$ & $88 / 158$ & $70 / 163$ & $72 / 179$ & $85 / 180$ & $84 / 180$ & $87 / 178$ & $95 / 180$ & $94 / 174$ & $94 / 174$ & $85 / 174$ \\
\hline $\begin{array}{l}\text { Rank } \\
\text { China }\end{array}$ & & $50 / 54$ & $41 / 52$ & $52 / 85$ & $58 / 99$ & $63 / 90$ & $57 / 91$ & $59 / 102$ & $66 / 133$ & $71 / 145$ & $78 / 153$ & $70 / 163$ & $72 / 179$ & $72 / 180$ & $79 / 180$ & $78 / 178$ & $75 / 180$ & $80 / 174$ & $80 / 174$ & $100 / 174$ \\
\hline
\end{tabular}

Source: Compiled from Transparency International CPI reports from 1995-2014. 
bullet trains was arrested for embezzling US\$ 2.7 billion in 2011. China issued a request for extraditing, Li Chang Xing, who was the chairman of Yuanhua International Corporation, trading in cigarettes who was supposed to have absconded to Canada with US\$ 7.7 billion. General XU Calhou, one of the senior generals was caught with cash, which needed 14 trucks to haul it away. Zhou Yongkong, the former security chief was the biggest 'tiger' caught till date. The other "tigers" who were arrested include Ling Jinhua, Jiang Jeminand Liu Tienan.

\section{Effects of Corruption on Foreign Firms}

Corruption in a country affects investors in many ways. First, it increases cost of doing business in a country. Second, it creates uncertainty for the corporation, if the process of obtaining required licenses involves discretion of politicians and bureaucrats. Third, it encourages middlemen to engage in corrupt activities. Fourth, the investors may have to face serious legal implications including prospect of going to jail, if they are caught. Fifth, they may be blacklisted by the host country and many other potential countries if it comes to light that the company engaged in malpractices. Sixth, the investing corporation might not be able to attract talented people in the host country. Seventh, the customer or public perception about unethical conduct can harm the brand image and reputation of the firm in the new host country. Eighth, it can harm the brand image in the home country as well. Ninth, it may result in financial damage in terms of fines imposed, even when the company does not admit guilt. Tenth and the gravest of all is corruption if tolerated in any form, tends to be accepted by society and becomes a way of life.

In 2010, Augusta Westland's won a contract for supplying 12 helicopters to the Indian Government by paying bribes. The resultant investigation led to the CEO going to jail (Magnier, 2013) [14]. Some other cases where foreign companies paid penalties in US for resorting to corrupt practices in India are, 2001-2005, Webtec (fine of US\$ 300,000 to DoJ, and $\$ 87,000$ in civil penalty), 2001-2003, Electronic Data Systems (CEO paid US\$ 70,000 fine and EDS separately paid \$ 490,902), 2003-2009, Global alcoholic beverages (paid disgorgement of US\$ 11 Million), 2010 Pride International (US\$ 32.6 million to DoJ and \$ 19.3 million to SEC.), 2011, Oracle corporation (US\$ 2 million fine) and 2014, Bharti WalMart (\$157 million in professional fee and $\$ 40$ million for FCPA compliance matters).

During 2012, China's State Administration for Industry and Commerce, a regulatory authority received investigated multinational company, Glaxo SmithKline (GSK), operating in China for indulging in massive corruption. According to their report, GSK set up units to bribe doctors and officials, for inflating the prices of their medicines, some times as much as 7 to 8 times, in return for bribes. It is alleged GSK has paid bribes to the tune of US\$ 490 million. GSK agreed with some of the charges and dismissed some its employees for wrong doing. Briton's Serious Fraud Office, a government body, announced launching of Criminal investigation in GSK. As a result of this the company lost US\$ 2.2 billion dollars in market capitalization (The Economist, 2014) [15].

The other firms affected by corruption are, JPMorgan Chase \& Co, the biggest US Bank and Avon Products Inc, a cosmetics company are facing investigation by US and Chinese authorities. Avon has spent more than $\$ 300$ million on investigating if their employees are involved in bribery. The company is also expecting heavy fines. Ex-Morgan Stanley real estate executive Garth, R. Peterson was sentenced to 9 months in prison, for illegal practices. Pfizer, another multinational drug manufacturer, paid US\$ 60.2 million to settle claims that it paid bribes to doctors in China. IBM paid \$11 Million fine for a similar reason involving China and South Korea (Voroacos, 2013) [16].

\section{Discussion and Findings}

In India, due to various investor friendly reforms FDI inflows started displaying a growing trend with inflows crossing US\$ 5billion during 2000 and continued to grow till 2008, reaching an unprecedented US\$ 42.55 billion. The most important factor during this period is that India has not witnessed any major corruption scam. However 2009 has also witnessed one of the biggest corporate scams in India, to the tune of US\$ 1.5 billion, involving the fourth largest IT firm at that time, 'Satyam Computers' listed on New York stock exchange and NASDAQ. Though the GDP and other economic indicators were showing a growth trend, FDI inflows have decreased by 44 percent from the 2008 level. In 2011 and 2012, notwithstanding a large growth in GDP, FDI has gone down by 45 percent and 42 percent respectively over 2008 levels, which can be attributed the major corruption scams Tatra truck scandal and Coalgate scam (US\$ 40 billion). This observation is supported by an ar- 
ticle in China Post, which has reported that the corruption in India has resulted in a slump of FDI by $78 \%$ in June 2011 (The China Post, 2011) [17]. The 2014 general elections in India resulted in change of the federal government with Bharatiya Janata Party winning an absolute majority for the first time in many decades. 2014 witnessed an increase of 24 percent in FDI over the previous year to US\$ 35 billion indicating support to the argument corruption indeed adversely affects FDI inflows.

Corruption in China is an unintended byproduct of the economic reforms initiated in the 1980s. China's culture of Guan $\mathrm{Xi}$ and acceptability of gift giving and receiving gifts, indirectly contributed to the increased corruption. However as the language, work culture, legal framework was totally different from capitalistic countries, the investors needed local partners to establish their business operations in China. Due to this decentralization local officials were given powers to approve many projects. This in turn has led to the increase in corruption, due to the discretionary powers enjoyed by officials. Statistics show that less than 3\% were caught for corruption before 2012. Hence many people started believing that the cost of involving in corrupt activity is more profitable and less risky than not engaging in such activities.

Many multinational companies on their part treated bribery as the additional costs of doing business and in spite of the corruption, the production costs were still much lower than their home countries and this made sense to enter China. This explains as to why that FDI inflows increased in China during the last three decades, making it the number one country in 2014, attracting highest amount of FDI, beating traditional favorite, the United States of America. However, as the problem of corruption appears to be spiraling out of control and with serious consequences socially and from foreign investors. Recently many foreign investors have started debating their options of moving to other countries. All these factors have culminated with the President of China announcing his big fight against corruption going after 'tigers and flys'.

\section{Conclusions}

A number of studies have empirically proven that corruption in a country adversely affects the inward flows of FDI. Each corruption scandal that came to light in India had an adverse effect on FDI inflows; the larger the scandal was, the higher the adverse nature of the impact would be. A study and simulation by Ketkar, Murtuza and Ketaker (2005) [18] regarding the link between Corruption Perception Index (CPI) of Transparency International (TI) and the FDI in 22 developing countries found that one point improvement in CPI would result in average additional FDI of $0.5 \%$. According to Wei (1997) [19], a well-known researcher in this area, a raise in the tax rate on multinational firms or increase in corruption levels in a host country reduces inward foreign direct investment (FDI). According to a study of data from 45 countries by Qian, Sandoval-Hernandez and Garrett (2012) [20], "corruption distance adversely influences both the likelihood of FDI and the Volume of FDI". Such corruption scandals are forcing the potential investors to look for opportunities in other developing countries. While India has experienced a decrease in FDI in 2011, Brazil's FDI inflows increase by $16 \%$ and reach US\$ 30.2 billion dollars. Due to the spate of corruption scandals, by February 2011, FDI in India fell more than $31 \%$ compared with the previous year, at a time when overall FDI and FDI into developing countries increased.

Corruption is a cancer that affects everyone, individuals, institutions, societies and countries and results in inefficient use of scarce resources and increases cost of transactions. Corruption diverts public money into private hands, which otherwise can have been used for economic and social development of country and eradicate poverty. In that context, corruption is anti-poor as the worst sufferers of consequences of corruption are poor people. Corruption breeds when there is no transparency and decision making authorities have discretionary power. China and India, in this paper, have some sound legal frame work to deal with corruption; however, the problem is with its enforcement.

One reason that China is able to attract FDI whereas India is not as successful lies in the nature of corruption in these countries. While analyzing corruption and its effects on their business investment opportunities in a particular country, firms look at two related issues, first, pervasiveness of corruption and second, arbitrariness of corruption. In China though corruption is pervasive arbitrariness is low. Whereas in India arbitrariness is very high and what it means is one not guaranteed of the result even after paying bribes. That partially explains why India's corruption has a detrimental effect on FDI, whereas in China, it has the opposite effect.

\section{References}

[1] UNCTAD (2014) World Investment Report. 
http://unctad.org/en/Pages/DIAE/World\%20Investment\%20Report/Annex-Tables.aspx

[2] International Monitory Fund (2014)

[3] IMF (2004)

[4] Anitha, R. (2012) Foreign Direct Investment and Economic Growth in India. International Journal of Marketing, Financial Services \& Management Research, 1.

[5] Alemu, A.M. (2012) The Effect of Corruption on FDI Inflow: Empirical Evidence from Panel Data of East Asian Countries. Seoul Journal of Economics, 25, 387-412.

[6] World Bank (2014) GDP Growth (Annual \%) Data. http://data.worldbank.org/indicator/NY.GDP.MKTP.KD.ZG

[7] The World Bank (2010) Foreign Direct Investment - The China Story. http://www.worldbank.org/en/news/feature/2010/07/16/foreign-direct-investment-china-story

[8] Klitgaard, R. (1995) International Cooperation against Corruption, Finance and Development. 3-6 March.

[9] Pathak and Prasad (2006)

[10] Lee, S.H. and Oh, K. (2007) Corruption in Asia: Pervasiveness and Arbitrariness. Asia Pacific Journal of Management. http://dx.doi.org/10.1007/s10490-006-9027-y

[11] Business Today (2014)

[12] Financial Times, Confidence in India's State Lenders Shaken by Bribery Scandal. 5 August 2014. http://www.ft.com/intl/cms/s/0/479968d4-1c99-11e4-98d8-00144feabdc0.html\#axzz3UrSnJ02z

[13] Huang, Y. (2015) Arresting Corruption in China-Why China's Form of Corruption Is So Unique? The Diplomat. http://thediplomat.com/2015/03/arresting-corruption-in-china/

[14] Magnier (2013)

[15] The Economist (2014) Corporate Corruption China. A Bitter Pill for GlaxoSmithKline. http://www.economist.com/blogs/analects/2014/07/corporate-corruption-china

[16] Voroacos, D. (2013) China's Bribery Culture Poses Risks for Multinationals. 20 November 2013. http://www.bloomberg.com/news/articles/2013-11-21/china-s-bribery-culture-poses-risks-for-multinationals

[17] The China Post (2011) India FDI Slumps 78 Percent in June over Corruption, Bureaucracy, Reform. http://www.chinapost.com.tw/business/asia/india/2012/08/25/352126/India-FDI.htm

[18] Ketakr, K.W., Murtuza, A. and Ketkar, S.L. (2005) Impact of Corruption on Foreign Direct Investment and Tax Revenues. Journal of Public Budgeting, Accounting \& Financial Management, 17, 313.

[19] Wei (1997)

[20] Qian, X., Sandoval-Hernandez, J. and Garrett, J.Z. (2012) Corruption Distance and Foreign Direct Investment. http://ssrn.com/abstract $=2076759$ http://dx.doi.org/10.2139/ssrn.2076759 